Revue

Revue de l'histoire des religions

del'histoire des religions

\title{
Religious Landscape and Sacred Ground: Relationships between Space and Cult in the Greek World
}

Paysage religieux et terre sacrée : rapports entre espace et culte dans le monde grec

\section{Marietta Horster}

\section{OpenEdition}

\section{Journals}

Electronic version

URL: http://journals.openedition.org/rhr/7661

DOI: 10.4000/rhr.7661

ISSN: 2105-2573

Publisher

Armand Colin

Printed version

Date of publication: 1 December 2010

Number of pages: 435-458

ISBN: 978-2200-92658-8

ISSN: 0035-1423

\section{Electronic reference}

Marietta Horster, «Religious Landscape and Sacred Ground: Relationships between Space and Cult in the Greek World », Revue de l'histoire des religions [Online], 4 | 2010, Online since 01 December 2013 connection on 21 December 2020. URL : http://journals.openedition.org/rhr/7661 ; DOI : https:// doi.org/10.4000/rhr.7661 


\section{Religious Landscape and Sacred Ground: Relationships between Space and Cult in the Greek World}

Modern studies of "sacred ground" have been influenced by Greek authors who emphasized its economic function. However, literary sources, sacred laws and various engravings stipulate that such land was not to be leased out. Theoretically, only ordinary territory provided revenue to religious sanctuaries, but available documents do not always make it possible to distinguish between the two types of land. Nonetheless, when sacred ground was farmed, it was no longer perceived as part of the religious landscape. Distinguishing markers were thus necessary to differentiate between sacred and common ground.

\section{Paysage religieux et terre sacrée:}

rapports entre espace et culte dans le monde grec

Les études modernes relatives aux « terres sacrées 》 ont été influencées par des auteurs grecs ayant mis l'accent sur leur fonction économique. Pourtant, les sources littéraires, les lois sacrées et diverses inscriptions stipulent que ces terres ne devaient pas être affermées. En théorie, seules les terres ordinaires apportaient des revenus au sanctuaire pour le culte. Cependant, la documentation ne permet pas toujours de départager ces terres. Néanmoins, lorsque les terres sacrées étaient cultivées, elles n'étaient plus perçues comme appartenant au paysage religieux. De fait, il était nécessaire de recourir à des marqueurs pour les distinguer des terres communes. 
It seems to be a matter of common knowledge that concepts of space are socially and culturally constructed and that these concepts are historically sensitive depending on the modern perspective of experience. ${ }^{1}$ Actually, "religious landscapes" have become a topic with some relevance since the last twenty years or so. However, the vagueness of the idea of concepts is often associated with a vagueness of terms attached to such contexts: religious landscapes, sacred space, land of the gods, paysage sacré, paysage religieux, terre sacrée, are often used without an explicit definition of what is meant and if there are differences in the use and meaning of these terms. For example, the term "ritual space" in combination with but different from "landscape" was used by Susan Guettel Cole with a focus on the study of the female cult, ritual and religion of Artemis in Ancient Greece. ${ }^{2}$ The variations and shifts in the meaning of the various terms may be as well indicated by the following titles of publications: Susan Alcock's and Robin Osborne's edited conference volume Placing the Gods. Sanctuaries and Sacred Space in Ancient Greece, the conferences on Classical, Jewish and other religious landscapes published by Benjamin Z. Kedar and R. J. Zwi Werblowsky in 1998 with the title: Sacred Space. Shrine, City, Land, or the conference-volume, Defining the Holy: Sacred Space in Medieval and Early Modern Europe published by Andrew Spicer und Sarah Hamilton in 2005. ${ }^{3}$

1. Susan Alcock, "Spaced-Out Sanctuaries: the Ritual Landscape of Roman Greece", in: Theoretical Roman Archaeology. First Conference Proceedings, ed. by Eleanor Scott, Aldershot 1993, pp. 155-165, esp. p. 156 with reference to YiFu Tuan, Topophilia: A Study of Environmental Perception, Attitudes and Fears, Englewood Cliffs 1980.

2. Susan Guettel Cole, Landscape, Gender and Ritual Space: the Ancient Greek Experience, Berkeley CA 2004, cf. ead., "Domesticating Artemis", in: The Sacred and the Feminine in Ancient Greece, ed. by Sue Blundel, Margaret Williamson, London 1998, pp. 27-43. According to Susan Guettel Cole, Artemis was "frequently worshipped" by young women "at the physical margins of the polis close to territorial frontiers" and "sanctuaries of Artemis was often located some distance from inhabited settlements, at the extremities of a city's territory. Sacred space on a border defined the limits of a city's territory. It protected the transitional area which divided one community from another" (p. 27 with references to François De Polignac's 1984 magisterial publication in its English translation: Cults, Territory, and the Origins of the Greek City-State, Chicago 1995).

3. The French volume on the Nature et paysage dans la pensée et l'environnement des civilisations antiques edited by Gérard Siebert in 1996 includes 
It seems that there exists neither a definition of the various terms, nor a coherent practical approach to use these terms-and that there is no established specific intellectual place and cultural context on which these terms are based ${ }^{4}$. In fact apart from "sacred land" the above mentioned terms reflect modern concepts but nothing ancient in Latin or Greek language comes near these notions and terms. To get closer to the term and concept of the "paysage religieux" one may first of all include as much as possible which might define this specific modern concept. In difference to the already antique term "sacred land" which is defined by the ownership of land by a deity regardless the lands' use and usage, the "religious landscape" has no such juristic and economic background and often no such pragmatic, practical basis.

Firstly, the notion of "religious landscape" includes the ritual and cultural practices in the sphere of religion. These cultural practices include the way processions take from one sanctuary to another, from inside the polis to a sanctuary in the chora or to a "sanctuaire limitrophe" at the very boundary of a polis' territory. It includes as well the itinerary a pilgrim is obliged to take or usually takes when approaching the sanctuary of his choice, the route which one has to take to a specific place where sacrifices and other religious rites take place. It includes the public or privately owned area surrounding a walled sanctuary not only with camping pilgrims, but also with fairs and markets, craftsmen and merchants who offer all kinds of services the pilgrims might need. ${ }^{5}$

many interesting subjects but nothing relevant for the discussion of the Greek sacred landscapes. Astonishing is the title (and content) of Jean Richer's book Géographie sacrée du monde grec, Paris 1967-the subtitle reveals that it is about the "croyances astrales des anciens Grecs", or as the English translation (Sacred Geography of the Ancient Greeks, Albany NY 1994) of the French 1983 second edition has put it: it is about the "astrological symbolism in art, architecture and landscape".

4. John Scheid's concluding paper in the volume: Sanctuaires, pratiques cultuelles et territories civiques dans l'Occident romain, Bruxelles 2006, p. 439-448 entitled "Paysage religieux et romanisation. Quelques réflexions en guise de conclusion", gives an idea of the broad dimension of the terms used in Roman religious studies: relation of city with its territory and the sanctuaries and cult sites of specific deities on the territory, the location of sanctuaries of "Roman" and of (more or less) local divinities and their places of veneration, etc.

5. Pierre Debord, Aspects sociaux et économiques de la vie religieuse dans l'Anatolie gréco-romaine, Leiden 1982, pp.11-17 on the role of markets for the attractiveness and prominence of sanctuaries; Matthew Dillon, Pilgrims 
The concept of "religious landscape" includes not only the just mentioned examples of temporary religious use of an often otherwise not sacred space, but secondly as well the sanctuaries in the chora of cities which define the civic territory by a twofold potential: by exclusion-of non-citizens, but also by inclusionuniting all inhabitants either of parts or of the entire territory (asty and chora) by the devotion of the deity concerned. ${ }^{6}$

The "religious landscape" concept includes, thirdly, all kinds of myths and of mythological traditions interweaved with the land and the polis. In the imagination of the people, e.g. the whole of Athens with Attica or specific parts of it may virtually become the territory, the religious landscape of Athena or of Poseidon or Dionysus-depending on the stories and myths related to a specific place or a larger region or city.

And it comprehends, fourthly, the "real", the judicially existing sacred space including sanctuaries and altars. This is the so-to-say real place and space of the gods. It consists of the monuments and the land the gods legally own-the land that is supposed as holy, that is protected by sacred laws, and for which sometimes regulations exist how to keep it pure and sacred. ${ }^{7}$

In my paper, I will focus on this last part of the various aspects of a religious landscape: the sacred land that is by definition the land

and Pilgrimage in Ancient Greece, London 1997, pp. 204-226 on the practical organisation of the festivals; Luuk DeLigt, Fairs and Markets in the Roman Empire, Amsterdam 1993, pp. 225-235 on panegureis as fairs of regional and sometimes of inter-regional importance; Alain Bresson, La cité marchande, Bordeaux 2000, pp. 174-178 discusses the question of fixed prices during religious festivals with markets. Livy 32.33 calls the Istmian Games the meeting place and market of Greece and Asia Minor, cf. Pol. 18. 44-48.

6. See François de Polignac, La naissance de la cité grecque: cultes, espaces et societés, VIII -VII siècles avant J.-C., Paris ${ }^{2}$ 1996, passim for the pre-classical function of cults at the border of the territories for the creation of civic identities. The idea of inclusion, of "contatto" (of indigenous italic people and Greek settlers) and not "frontier" of rural sanctuaries in Magna Graecia is underlined by Guglielmo Genovese, I santuari rurali nella Calabria Greca, Roma 1999, esp. p. 208, similar but with a focus on the regional religious identity of smaller units: Lorenz E. Baumer, Kult im Kleinen. Ländliche Heiligtümer spätarchaischer bis hellenistischer Zeit: Attika-Arkadien-Argolis-Kynouria, Rahden, Westf. 2004, pp. 9-11 and passim.

7. Robert Parker, Miasma. Pollution and Purification in Ancient Greece, Oxford 1983, pp. 144-190; Marietta Horster, Landbesitz griechischer Heiligtümer in spätarchaischer und klassischer Zeit, Berlin 2004, pp. 49-52 on the "holiness" of land, pp. 92-138 on regulations concerning the purity and sacredness. 
owned by the gods and deities. ${ }^{8}$ From Classical to Roman times, the land owned by gods was perceived and thus used quite differently. There seems to exist a kind of hierarchy of sacredness a land might possess, without that this hierarchy was ever defined with judicial consequences. On the one hand, there existed land of the gods that was strictly defined as a kind of untouchable and holy territory. Examples are the sacred groves and springs, not only the home of the nymphs but also attested for Zeus at Olympia and Labraynda, ${ }^{9}$ for Apollo Gryneios in the Aeolis, ${ }^{10}$ for Apollo Kyparissios and Asclepios at $\operatorname{Cos},{ }^{11}$ and for many other gods and deities in other places and regions all over Greece and Asia Minor. The holiness of such sacred land was often protected by rules of conduct and by prohibitions. However, this was only one means to enhance the sacredness of the land and importance of the deity who owned this land.

On the other hand, the importance of a deity could be visualised by the wealth of a cult. The cult's property was of major relevance for the perception of the deity's prominence and power. A vast amount of sacred land supposed to finance the cult and the sanctuary proved the deity's outstanding role. Such landed property was often leased out so that the revenues of the incoming rents would feed the god. The money would then run the sanctuary, pay for the sacrifices and other rituals, pay for the upkeep and maintenance of existing structures, and finance the building operations in and for the sanctuary.

The sacred land of the gods, their property, was used variably, and its use could change if the god's property-administrating institution decided on the subject. The responsible institution was the demos

8. Contra the arguments of Moses I. Finley, Studies in Land and Credit in Ancient Athens 500-200 BC. The horos-inscriptions, New York $1973^{2}$, esp. p. 95 that the gods' and deities' ownership of the land did not matter as all, but that this land was regarded and treated as part of the public land, see Signe Isager, Sacred and Profane Ownership of Land, in: Berit Wells (ed.), Agriculture in Ancient Greece. Proceedings of the Seventh International Symposium at the Swedish Institute at Athens, 16-17 May, 1990, Stockholm 1992, pp. 119-122 and with a different argumentation M. Horster, Landbesitz, pp. 9-15.

9. A sacred grove of sycamore trees: Natascha Kreutz, Zeus und die griechische Polis. Topographische und religionsgeschichtliche Untersuchungen von archaischer bis in hellenistische Zeit, Rahden/Westf. 2007, $135 \mathrm{f}$.

10. Guiseppe Ragone, "Il tempio di Apollo Gryneios in Eolide", Studi Ellenistici 3 (1990), pp. 9-112, esp. pp. 90-94.

11. $L S C G 150 \mathrm{~A}$ dated with all probability to the late $5^{\text {th }}$, and $\mathrm{B}$ dated to the fourth century BC. 
and boule in the case of most of the public cults, or the assembly of a private cult organisation in the case of the many privately organised cults

\section{HOROI, BOUNDARY STONES AS MARKERS OF A SACRED TERRITORY}

In Greek speaking regions the landed property of the gods and deities was often marked by horoi, boundary stones that indicated the bounds of temene-sacred land (sanctuaries as well as agricultural estates and meadows, groves and woods, fallow land and land used for specific rituals in the context of a cult). ${ }^{12}$ Some of the horoi from the island of Aigina give an idea of the dispersion: at least three horoi have "a clear line of sight" and have a distance of only $150-350 \mathrm{~m}^{13}$

The horoi were inscribed: horos, horos temenos, horos temenos + deity, horos + deity, hiera ge, hiera... etc. The short text indicated that-regardless of the specific character of the land, cultivated, used for grazing of the god's cattle, leased out or left as uncultivated wild nature-at the very point where a horos was placed there was the property of a god. It did not indicate the limitation of public or private land, but most often the beginning of a specific kind of property, the sacred land. ${ }^{14}$ It is unknown how many such boundary stones did not carry inscriptions. What we usually identify are the inscribed horoi, that indicate that the land beyond this stone belongs either to a sanctuary or to a god-both expressions are well attested

12. Irena Polinskaya, "Fifth Century Horoi on Aigina. A Reevaluation", Hesperia 78 (2009), pp. 231-267, esp. p. 264 assumes that the position of the temenos of Athena on Aigina near Sphendouri with rocky soil has a "strategic purpose." Grazing ground has more plausibility. See below for pastoralism and for grazing flocks on sacred lands.

13. Ibid., esp. p. 239f.

14. For the various ideas and concepts, modern and ancient, of frontiers and boundaries, see the analytic overview of the scholarship on frontiers by Giovanna Daverio Rocchi, "Quindici anni di studi sulle frontiere della Grecia antica: alcune prospettive della ricerca", in: Ulrich Fellmeth et al. (ed.), Historische Geographie der Alten Welt: Grundlagen, Erträge, Perspektiven. Festgabe für Eckart Olshausen aus Anlass seiner Emeritierung. Hildesheim 2007, pp. 87-105. Joshua Ober, "Greek Horoi: Artifactual texts and the contingency of meaning", in: David B. Small (ed.), Methods in the Mediterranean. Historical and Archeological Views on Texts and Archaeology, Leiden 1995, pp. 91-123, with rather wide implications as to the function of horoi. 
and seem to have been compatible. ${ }^{15}$ The earliest attested horoi of sanctuaries with inscriptions date to the sixth century (Artemision at Lemnos), the number of conserved horoi of sacred land increases from the fifth century onwards but diminishes again in the late Hellenistic and Roman Imperial period. In addition to the horoi themselves, we have testimonies concerning boundary disputes in which a land survey was ordained and the setting of new boundary stones prescribed. As the average size of such horoi is rather small, often some $30-40 \mathrm{~cm}$ over ground, they may not have been visible from a distance, and therefore have only been regarded as visible markers of a sacred territory when seen close-by. The horoi legally delimitated the property, the land of the gods. However, one may doubt if the existence of scattered small boundary stones did work

15. List with horoi of late archaic and classical times in M. Horster, Landbesitz, pp. 23-33. For detailed studies see Gerald V. Lalonde, Horos Diois. An Athenian Service and Cult of Zeus, Leiden 2006, pp. 1-11 (on $I G \mathrm{I}^{3}$ 1005A\&B), I. Polinskaya, "Fifth-Century Horoi on Aigina" with a discussion of the now known 18 Attic horoi of Aiginetan territories dedicated to Athenian gods, which were probably meant to finance the newly established Athenian cults in Aigina the Athenian settlers on Aiginea worshipped and not as Polinskaya took it, to add to the budget of the Athenian cults in Athens. Apart from the Athenian-Aigina horoi, recently published horoi of sacred land of the Classical period include: Rhamnous, Attica, SEG 49 (1999) 179; Argos, SEG 42 (1992) 274, Shrine of the Seven against Thebes, ca. $550 \mathrm{BC}$; more of the already known stones (IG XII 2. 521) from Methymna, Lesbos, SEG 45 (1995) 1085; Aigina boundary stones of non-Athenian cults $I G$ $I^{2}$ 2.788-791 (Apollo, Zeus and unkown deities); SEG 49 (1999) 1173 Thasos, cult of Kore ca. 350 BC; SEG 50 (2000) 622 Pydna in Macedonia, $5^{\text {th }}$ cent. BC, a boundary stone perhaps of property of Pan Naios; SEG 54 (2004) 792-794, cf. IG XII 5. 48, Naxos, sanctuary of Zeus Melosios, $4^{\text {th }}$ cent. BC. Recently published horoi of sacred land dated to the Hellenistic period: Attica, SEG 41 (1991) 123, cf. 45 (1995) 163 sanctuary of Meter in Melissia (Phyla), $2^{\text {nd }}$ cent., SEG 44 (1994) 79 temenos of Asklepios and Hygeia, $2^{\text {nd }}$ cent. BC; SEG 41 (1991) 907 Amyzon, Caria boundary stone indicating the asylia-area of the Artemis-temple; SEG 43 (1993) 797 Ephesus, late Hellenistic (?) of unknown sanctuary; SEG 45 (1995) 1583 Ephesus, late Hellenistic period, land of Artemis used for raising horses; SEG 49 (1999) 353 Argos, property of Zeus Eubouleus, Hellenistic period; I. Histriae 105/6 Histria boundary stones of sanctuaries of Apollo Pholeuterios and Phorkys, $3^{\text {rd }}$ cent. BC; SEG 51 (2001) 1104 Eretria, Euboia of unknown sanctuary, undated. Recently published horoi of sacred land dated to the Roman Imperial period: Gerald V. Lalonde, Merle K. Langdon, Michael B. Walbank, Inscriptions: Horoi, Poletai Records, Leases of Public Lands. (The Athenian Agora vol. 19), Princeton NJ 1991, 26-27 H 23-24 ( $2^{\text {nd }}$ cent. AD, land of Athena Polias), e.g. $I G \mathrm{I}^{2} 865 \mathrm{~b}$, SEG 10 (1949) 363 with an archaizing inscription (temenos of Artemis Amarysia, ca. AD 125-75), $I G$ IX $1^{2} .1 .80$ Thermos, Aetolia ( $2^{\text {nd }}$ cent. AD): SEG 41 (1991) 318 Sparta, boundary stone of temple precinct, first century AD; SEG 39 (1989) 1102 Aprodisias, Caria after $39 \mathrm{BC}$, belonging to the sanctuary of Aphrodite. 
to delimitate visually the land of the gods, if they really did and could accentuate the landscape and characterise a "landscape" as "religious" or "sacred."

These legally binding markers of sacred land identified land often adjoining to a sanctuary with temple or a cult-place with altar. In many cases, it was, however, not directly connected with the sanctuary or the main altar. In these cases, the context of the sacred status of land was even less recognisable, even if marked by boundary stones-which was obviously, as several boundary disputes attest, not always the case. ${ }^{16}$ In addition, boundary stones were sometimes used to demarcate other kinds of landed property, not very often private property and even less public land, especially in the case when it was leased out or in the case of private property given as a security for a loan. ${ }^{17}$ For those who could not read as for everyone more distant than a couple of meters, the boundary stones in the landscape thus indicated in most cases-regardless the text of the inscription-that at this point, at least two different owners of landed property did exist, and that-in accordance with the mass of surviving horoi-the land beyond the demarcation belonged to all probability to a deity.

\section{(Greek) Sources on SACRed Land}

Apart from the horoi there are as well other ancient sources attesting the existence and usage of sacred land. The groups of testimonies may be summarised as follows:

1) Theoretical or philosophical texts (see below for a discussion of some of the earliest)

2) Literary, anecdotal evidence, like Xenophon's account of his donation of a sanctuary of the Ephesian Artemis with a wide-

16. On disputes over territories, e.g. Angelos Chaniotis, "Habgierige Götter, habgierige Städte. Heiligtumsbesitz und Gebietsanspruch in den kretischen Staatsverträgen", Ktema 13 (1988), pp. 21-39, and Kaja Harter-Uibopuu, Das zwischenstaatlische Schiedsverfahren im achaischen Koinon, Köln 1998, discusses inter alia 12 inscriptions concerning border settlements and boundary disputes.

17. For horoi as attestations of private property especially in cases of security loans, see e.g. Louis R. F. Germain, "Les Horoi", in: Joseph Modrzejeski, Dieter Nörr (eds.) Symposion 1971. Vorträge zur griechischen und hellenistischen Rechtsgeschichte, Köln/Wien 1975, pp. 333-346, Diederich Behrend, Attische Pachturkunden, München 1970, passim. Horoi of public land are attested only rarely, one such might be $S E G 41$ (1991) 723 Dystos, Euboia. 
stretching estate, which was at least partly leased out to secure the maintenance of the cult (Xen. Anab. 5.3.7-13), or again like Pausanias' description of a deteriorated landscape with formerly strong pious poleis and the still standing monuments of religious piety and the ruins of sanctuaries and altars, reminding the contemporary readers of the once past religious strength. ${ }^{18}$

3) Epigraphic evidence concerning the property of the gods and deities like information provided in sacred laws, which define the use of the gods' land. Such laws have no general validity for all sanctuaries of a polis, but concern only one specific sanctuary or cult. ${ }^{19}$ These regulations may concern the interdiction to remove wood, brushwood and dry sticks or they may list certain privileges such as revenues and resources, tax exemptions or asylia. Other sacred laws concern exclusively the regulations for the leasing of the lands often combined with detailed guidelines on how the land should be used, what kind of crops should be cultivated. Inscriptions with another character are those that consist of lists of land-lots and names of the leaseholders. Such inscriptions are known for example of some of the $4^{\text {th }}$ century Demes' sanctuaries in Attica, ${ }^{20}$ of the large estates of Apollo at Delos and Rheneia from the late forth into the second century $\mathrm{BC},{ }^{21}$ or of the leasing-documents from Mylasa in Asia Minor. ${ }^{22}$

These various kinds of testimonies for sacred land may have an impact on the (ancient) structure and (modern or ancient) perception

18. Vinciane Pirenne-Delforge, Retour à la source. Pausanias et la religion grecque, Kernos Supplément 20, Liège 2008.

19. Overview over the various functions and concerns of sacred laws are presented by Robert Parker, "What are Sacred Laws?", in: Edward M. Harris, Lea Rubinstein (eds.), The Law and the Courts in Ancient Athens, London 2004, pp. 57-90, and by Eran Lupu, Greek Sacred Law. A Collection of New Documents (NGSL), Leiden/Boston 2005, pp. 9-112, on sanctuaries and sacred space esp. pp. 9-40.

20. D. Behrend, Attische Pachturkunden; David Whitehead, The Demes of Attica 508/7 - c. 250 BC. A Political and Social Study, Princeton, NJ 1986; John Davies, "Temples, Credits, and the Circulation of Money", in: Kirsty Shipton, Andrew Meadows (eds.), Money and its Uses in the Ancient Greek World, Oxford 2002, pp. 117-128.

21. John H. Kent, "The Temple Estates of Delos, Rheneia, and Mykonos", Hesperia 17 (1948), pp. 243-338; Claude Vial, Délos indépendante (314-167 avant J.-C.), Paris 1984, esp. pp. 317-347; Gary Reger, Regionalism and Change in the Economy of Independent Delos, Berkeley/Los Angeles 1994.

22. Beate Dignas, Economy of the Sacred in Hellenistic and Roman Asia Minor, Oxford 2002, pp. 95-106. 
of the landscape they concern and may influence the-real or virtual, piously created or intellectual-formation of a religious landscape. In addition to the varieties of modern concepts for religious landscapes, there was as well no standard handling or management of the sacred land in Ancient Greece and other regions: neither for one deity, nor in one city, nor at a given time. However, one important attitude was constant: the votives, the cult equipment, the sanctuaries and shrines and the landed property-all property of the gods was intangible and indefeasible. It was a sacrilege to expropriate, to seize such property. In exceptional cases however, the institutions, public or private which were responsible for the administration of the cult, the sanctuary and the property of the respective deity concerned, could decide on the conversion, transformation or use of the already existing property. Such decisions concerned for example the melting of old votives to make new votives, the temporary use of a deities' property to take a loan, or the changes in the agricultural-utilisation or non-utilisation or leasing out of landed property which was until now not leased out. ${ }^{23}$

One such example of a (finally fruitless) discussion on the conversion of the use and character of sacred land comes from fourth century Athens: The Sacred Orgas inscription $\left(I G \mathrm{II}^{2} 204\right)$ relates in the conserved decree the provision of horoi to secure the line of border for the Sacred Orgas, the land that had to be left uncultivated according to divine orders. The horoi demarcating the sacred land had disappeared and the borders of the land belonging to Demeter and Kore were obviously no longer sufficiently respected. Athenians, private owners of adjacent land, thus cultivated parts

23. Use or melting of votives to shape new votive, e.g. IG VII 303 (= V. Petrakos, IOropos 324) ca. 240 BC, referring to the sanctuary of Amphiaraos; for the melting of votives in fourth century Athens, see Diane Harris, "Bronze Statues on the Athenian Acropolis. The Evidence of a Lycurgan Inventory", American Journal of Archaeology 96 (1992), pp. 657-652, and Richard Hamilton, Treasure Map. A Guide to the Delian Inventories, Ann Arbor 2000, p. 253 note 40 on the meltdown of votives probably in the period between 411 and $403 \mathrm{BC}$. For the discussion of the agricultural usage of the hiera orgas in Athens, see below (with note 24). Athena and other deities loaned money to the Athenian people that was to be paid back, cf. $I G \mathrm{I}^{2} 91 / 92=I G \mathrm{I}^{3} 52$ (Kallias Decrees of 434/33 BC); in the third century, the city of Acraephia, Boetia mortgaged sacred land for a short term, SEG 3. 359. On hellenistic developments in the treatment of the properties of the gods and the use of sacred land as a security for public loans, M. Horster, Landbesitz, pp. 47-49. 
of the sacred land. In 352/51 BC the Athenian assembly saw this incident as a chance to reorganise the cult-finances by ameliorating the funding-base of the Demeter and Persephone cult by changing the status of the uncultivated sacred land into a leased out cultivated land. However, for such an alteration in divine matters (probably based on a god's will in the mythological past), Apollo's decision was needed-which as the inscription relates-was not given. ${ }^{24}$

Apart from the clearly marked out walled sanctuaries and shrines, some of the sacred trees, holy places marked by thunderbolts, sacred groves, sacred springs, sacred grottos, sacred caves and other natural holy places might have been marked out as well by boundary stones or encircling walls or fences. In other cases, the knowledge and narrated tradition by the people living near such naturally holy places might have been the only way to learn where such places were, what constituted their holiness, which gods or deities owned the place. We do not know if someone who entered such an unmarked natural sacred space recognised such a place immediately, had a specific experience, a holy frisson, an amazement of the difference and specific quality of the world he or she just entered. ${ }^{25}$ In our modern knowledge and assumptions we are reduced to literary notes and epigraphical hints to receive a restricted, reduced view on the sacred land and, if at all, the ways by which it became part of a "religious landscape". As already said, the anecdotal literary evidence as the epigraphic evidence demonstrate that there was no clear and global trends concerning the landed property of the gods. It cannot be observed that at a given time (or in a larger region) there was a tendency to augment the extension of the sacred land and to increase the number of land-lots, so that leasing out the land guaranteed and probably increased the

24. On the political and judicial context and its implications, J. McDonald, "Athens and the 'Hiera Orgas"”, in: Matthew Dillon (ed.), Religion in the Ancient World. New Themes and Approaches, Amsterdam 1996, pp. 321-332; Adele Scafuro, "IG II ${ }^{2}$ 204: Boundary Setting and Legal Process in Classical Athens", in: Gerhard Thür, Francisco J. Fernández Nieto (eds.), Symposion 1999. Vorträge zur griechischen und hellenistischen Rechtsgeschichte, Köln/Weimar/Wien 2003, pp. 123-143.

25. For the specific (more or less impressive) characteristics of sacred caves and grottos, see Katja Sporn, "Höhlenheiligtümer in Griechenland", in: Christian Frevel, Henner v. Hesberg (eds.), Kult und Kommunikation. Medien in Heiligtümern der Antike, Wiesbaden 2007, pp. 39-62. 
revenues and thus cult-income, hence, secures the maintenance of the sanctuary and the financing of sacrifices, rituals, festivals of the cult. In addition, there was obviously a lack of a consistent planning concerning the economic efficiency of cults and sanctuaries. Modern attempts to combine the assumed efficiency-intention with the handling of landed property of the gods, or for example with the sale of priesthoods, does not work. The leasing of land does not seem to have been a routine kind of basic income for all cults in Greece, Asia Minor or Western Greece from Classical times to the Roman Imperial period, and the sale of priesthoods was likewise uncommon or at least not widespread. Most of the Greek-speaking regions (like the whole of Greece) did not make use of the priesthood-sales as a possibility to guarantee income and upkeep of a cult. In Greece at least, religious traditions as well as specific political attitudes were obviously speaking against the sale of priesthoods for public cults. ${ }^{26}$ Moreover, religious traditions as well as probably quite practical reasons like the lack of masses of public land as disposable quantity out of which more parts for the gods could have been taken, might have been the main reasons why the leasing out of land-lots as an income for the gods was (most often) not augmented over time and why it was not always used as an effective means in times in which the cult-revenues did not suffice.

\section{Sacred Land in Ancient Cultural and Political Theory}

In difference to what the philosophical and theoretical texts do suggest, not all cults and not all gods in all cities had their own landed property, as it seems. Four philosophical treatise and theoretical texts, which offer different aspects of the function of sacred land, may illustrate the variants in approach to the subject and the far from unanimous notions of sacred land in the theoretically motivated literature of classical times.

26. On the sale of priesthoods with reference to modern literature and ancient sources, Marietta Horster, "(Weibliche) Priesterämter in griechischen Städten - Bemerkungen zum Wandel in der Überlieferung", in: Lukas de Blois, Peter Funke, Johannes Hahn (eds.), The Impact of Imperial Rome on Religions, Ritual, and Religious Life in the Roman Empire, Leiden/Boston 2006, pp. 194-207, esp. p. 196-200. 
In the last quarter of the fifth century BC, Hippocrates wrote a treatise "On the sacred disease". He discusses causes and remedies for pollution, and the role the gods take in the purification of the polluted. In this text he mentions his opinion concerning the boundaries of sacred land (Morb.Sacr. 1.46). ${ }^{27}$

Hippocrates clearly defines the function of the marked sacred boundaries: it is a stop and a reminder to the pilgrim not to enter the sacred place polluted, so that one enters the sacred place only after purification. ${ }^{28}$ This has nothing to do with cult-economy but with ideas of religion, of human miasma, pollution and the role of purification. In addition, according to Hippocrates, these boundaries were made by man, they were decided on by the community for just this very purpose, the appropriate veneration and worship of the gods and deities only purified men and women could accomplish. Marked boundaries should therefore safeguard men of ignorance of the specific sacred status of a grove or shrine. This might as well allow the conclusion that the sacredness of places (especially without monuments like temples) would probably not always be easily detected-which would as well have consequences for the discussion on the relation of sacred land and "religious landscapes". Hippocrates has presented in his study a specific concept of pollution and purification with its consequences for the sacred property and the sacred land the pilgrim wants to enter.

However, already in the fifth and then in the fourth century, there existed other contexts of reasoning and of discourses on sacred land. Like Hippocrates, Hippodamus in the fifth, and Plato and Aristotle in the fourth century, speak of man-made boundaries of sacred land. But all three authors chose another perspective than Hippocrates

27. Transl. Francis Adams in: The Internet Classics Archive, http://www. classics.mit.edu: "Neither truly do I count it a worthy opinion to hold that the body of man is polluted by god, the most impure by the most holy; for were it defiled, or did it suffer from any other thing, it would be like to be purified and sanctified rather than polluted by god. For it is the divinity which purifies and sanctifies the greatest of offenses and the most wicked, and which proves our protection from them. And we mark out the boundaries of the temples and the groves of the gods, so that no one may pass them unless he be pure, and when we enter them we are sprinkled with holy water, not as being polluted, but as laying aside any other pollution which we formerly had. And thus it appears to me to hold, with regard to purifications."

28. R. Parker, Miasma, pp. 19-21 on Hippocrates, cleanliness and purity, lustral bowls at the entrance of shrines. 
and concentrate exclusively on the economic and political aspects of sacred land. ${ }^{29}$

Aristotle (Politics 1267b 30-37) relates Hippodamus of Miletus' proposal of the best way to plan and found a new city. The land should be divided into three parts: sacred land, hiera, public land, demosia, and private land, idia. This partition receives a political and economic justification based on a specific idea and concept of polis-societies:

"The city of Hippodamus was composed of 10,000 citizens divided into three parts-one of artisans, one of peasants, and a third of armed defenders of the state. He also divided the land into three parts, one sacred, one public, the third private: the first was set apart to maintain the customary worship of the Gods, the second was to support the warriors, the third was the property of the peasants. ${ }^{.30}$

In all three cases, the landed property was to guarantee a basic and sufficient income to the three groups of property-holders: the gods, the warriors and the peasants. Plato in the Laws (Nom. 738b-d; 745d-747e) ${ }^{31}$ as well as Aristotle in his Politics (Politics

29. For the respective political context of these three texts, see M. Horster, Landbesitz, pp. 66-68.

30. Transl. Benjamin Jowett in: The Internet Classics Archive http://www. classics.mit.edu. Arist. Pol. II 8. He uses the term "husbandsmen" for peasants.

31. Transl. Benjamin Jowett in: The Internet Classics Archive http://www. classics.mit.edu. Plato, Laws V: "How then can we rightly order the distribution of the land? In the first place, the number of the citizens has to be determined, and also the number and size of the divisions into which they will have to be formed; and the land and the houses will then have to be apportioned by us as fairly as we can. Whether the legislator is establishing a new state or restoring an old and decayed one, in respect of Gods and temples-the temples which are to be built in each city, and the Gods or demi-gods after whom they are to be called-if he be a man of sense, he will make no change in anything which the oracle of Delphi, or Dodona, or the God Ammon, or any ancient tradition has sanctioned in whatever manner, whether by apparitions or reputed inspiration of Heaven, in obedience to which mankind have established sacrifices in connection with mystic rites, either originating on the spot, or derived from Tyrrhenia or Cyprus or some other place, and on the strength of which traditions they have consecrated oracles and images, and altars and temples, and portioned out a sacred domain for each of them. The least part of all these ought not to be disturbed by the legislator; but he should assign to the several districts some God, or demi-god, or hero, and, in the distribution of the soil, should give to these first their chosen domain and all things fitting, that the inhabitants of the several districts may meet at fixed times, and that they may readily supply their various wants, and entertain one another with sacrifices, and become friends and acquaintances; for there is no greater good in a state than that the citizens should be known to one another." 
1329b-1330a) ${ }^{32}$ confirm Hippodamus' target course, that the gods should receive a part of the land, so that the sacred land should safeguard the maintenance of cults and sanctuaries. Their respective argumentations differ, as do their concepts of societies and polisstructures.

In his exposé of his socio-political concept, in one short passage, Plato argues for a second, an additional part of the land the gods should receive:

"The least part of all these ought not to be disturbed by the legislator; but he should assign to the several districts some God, or demi-god, or hero, and, in the distribution of the soil, should give to these first their chosen domain and all things fitting, that the inhabitants of the several districts may meet at fixed times, and that they may readily supply their various wants, and entertain one another with sacrifices, and become friends and acquaintances; for there is no greater good in a state than that the citizens should be known to one another." 33

In this theoretical concept of sacred land, the land becomes a political-religious landscape so-to-say with strong social implications: the main reason for the existence of this land is the coming together of all citizens-the land and thus the honour of the gods seems only a kind of neutral implement for the gatherings.

The various antique philosophical and political justifications for the division of land has instigated a modern discussion about the status of the sacred land-if it is a subdivision of the public land, like in the concept of Aristotle, or a legal construct on its own, like in Hippodamus' and Plato's argumentations. But apart from the often attested Greek terms and notions of the separate existence of "sacred land", the modern discussion on the legally/politically handling of sacred land does not matter for a debate of the relation of sacred land and religious landscape. Hippodamus', Plato's and Aristotle's

32. Transl. Benjamin Jowett in: The Internet Classics Archive http://www. classics.mit.edu. Arist. Pol. 1330a 10-15 = VII 10: "The expense of religious worship should likewise be a public charge. The land must therefore be divided into two parts, one public and the other private, and each part should be subdivided, part of the public land being appropriated to the service of the Gods, and the other part used to defray the cost of the common meals; while of the private land, part should be near the border, and the other near the city, so that, each citizen having two lots, they may all of them have land in both places; there is justice and fairness in such a division, and it tends to inspire unanimity among the people in their border wars."

33. Plat., Nom. 738b, see note above with the full text and context. 
respective economic reasoning, however, does matter, as it matches with the inscriptional evidence that concerns sacred land.

\section{Economic And Non-Economic Usage of SACred LANd}

The existence of sacred land as well as its multifaceted function (to finance a cult, to increase the solidarity of the citizens, to enhance the sacred status of the deities' belongings, etc.), continued into Roman times, even if there seems to be an Imperial-time-trend of a decline in the effectiveness, intensity and/or traditions of land use in many (or at least some) regions of Greece, which might have affected the leasing out of sacred land as well. ${ }^{34}$ Nonetheless, inscriptions attest many land-leases of sacred land, disputes over land boundaries and land-property of deities and gods etc. since the fifth century BC well into Roman times. ${ }^{35}$ Donations of land to sanctuaries or gods (the phraseology in the inscriptions vary) are attested for Hellenistic kings, Roman emperors and private benefactors. Moreover, privileges for sanctuaries granted by Hellenistic kings and later by the Roman senate or the emperor had in most cases economic consequences for the sanctuary and the city-the asylia, the panhellenic festivals, the regulations and privileges for markets and fairs in connection with sacred feasts. ${ }^{36}$

34. For changes in land-use in Roman Imperial Greece, see Signe Isager, Jens Erik Skydsgaard, Ancient Greek Agriculture, London/New York 1992, p. 120; a more general approach focused on the assumption of demographic change is presented by Susan Alcock, Graecia Capta. The Landscapes of Roman Greece, Cambridge 1993,pp. 33-92 on the "rural landscape", and with a different perspective (places of cult, imperial cult etc.), pp. 172-214 on the "sacred landscape". A critic on generalisations as to the "decline" of cities and their respective chora in Hellenistic and Roman Greece is presented by Denis Rousset, "The City and its Territory in the Province of Achaea and 'Roman Greece"', HSCPh 104 (2008), pp. 303-337 (less elaborated idem, "La cité et son territoire dans la province d'Achaïe et la notion de 'Grèce romaine'”, Annales 59 (2004), pp. 363-383.

35. For landleases of the classical period, see M. Horster, Landbesitz, pp. 139-191; for later periods (Greece and Asia Minor), Pierre Debord, Aspects sociaux et économiques de la vie religieuse dans l'Anatolie gréco-romaine, Leiden 1982, esp. pp. 139-180; Robin Osborne, "Social and Economic Implications of the Leasing of Land and Property in Classical and Hellenistic Greece", Chiron 18 (1988), pp. 279-323 discusses Athens $\left(5^{\text {th }}\right.$ and $3^{\text {rd }}$ cent. BC), Delos (late $4^{\text {th }}-$ $3^{\text {rd }}$ cent. BC), Thespiai ( $3^{\text {rd }}$ to $2^{\text {nd }}$ cent. BC), Khartaia on Keos ( $3^{\text {rd }}$ cent.).

36. Laura Boffo, I re ellenistici e i centri religiosi dell' Asia Minore, Florenz 1985; P. Debord, Aspects sociaux, pp. 144-162; Beate Dignas, Economy of 
But there exists as well the opposite aspect attested in literary sources and inscriptions-the explicit and intended non-economic use of sacred property including the sacred land. Already mentioned is the prohibition of agricultural usage for economic purposes of the Hiera Orgas belonging to Demeter and Kore at Eleusis. ${ }^{37}$ In this case, in 352/51 the Apollo-oracle at Delphi forbade the agricultural usage and thus the leasing out of the land in order to maintain its sacredness and to observe the religious traditions. A second example of this kind is the arbitral verdicts and accounts of disputes between several poleis on the isle of Crete. In the case of Hierapytna and Itanos, the conflict concerned land: the Hierapytnaeans stated that it was the sacred land of Zeus Ditaios, a cult probably organised and maintained by the city of Hierapytna. The Itanaeans, however, argued that the land was agriculturally used, cultivated and had at least one building on it, thus, obviously it could not be the property of a god. ${ }^{38}$ The Megarian arbitrators followed the argument of the Itanaeans in two separate decisions. The sacred character of the cultivated land was inconceivable-at least for the Itanaeans and the Megarians. A third and last example are the Delphian Apollo's sacred lands with a vast extention of 150 to $200 \mathrm{~km}^{2}$ partly agriculturally used, partly left uncultivated, that produced several disputes, even wars. ${ }^{39}$ The

the Sacred in Hellenistic and Roman Asia Minor, Oxford 2003, passim; Klaus Bringmann, Geben und Nehmen. Monarchische Wohltätigkeit und Selbstdarstellung im Zeitalter des Hellenismus, Berlin 2000, pp. 97-107 (chapter: "Die Fürsorge für Heiligtümer und Kulte"). Kings: e.g. Eumenes I Philetairos donates land to Apollo Chresterios at Aigai (Aiolis) 263-241 BC, SEG 49 (1999) 1746; Romans: e.g. Caesar confirms the right of asylum to the sanctuary of Artemis in Sardis, SEG 39 (1989) 1290. Private benefactors that dedicate land to gods are e.g. in the late fifth century, Nicias dedicated land to finance a festival of Apollo at Delos (Plut. Nic. 3.6); after $240 \mathrm{BC}$, in Carian Labraunda, Olympichus, governor of Seleucus II, had dedicated his own land to Zeus. The incoming rent should finance a monthly panegyris of Zeus Osogoa, I Labraunda 1.8 .

37. This concerns firstly a dispute over illegal usage by the Megarians in the 430 s and secondly, a discussion of the demos about the economic potential to be used for the sanctuary's income, $I G \mathrm{II}^{2} 204$, on which see above with note 24 .

38. A. Chaniotis, "Habgierige Götter", pp. 38-39 with Testimonia 6 and 7: the Magnesians' first judgement was made shortly after 141 BC, the second arbitration in 113/12 BC, confirmed the first judgement in favour of the Itaneans.

39. Dimension: Denis Rousset, "Terres sacrées, terres publiques et terres privées à Delphes", CRAI (2002), pp. 215-241, esp. p. 226. Disputes and wars: Denis Rousset, Le territoire de Delphes et la terre d'Apollon, Paris 2002, esp. pp. $85-108$, translates and discusses the second century BC to the second century $A D$ inscriptions of the disputes, arbitrations and regulations regarding the limitation of the Apollonian land; for the late archaic and classical evidence and 
non-agricultural usage of Apollo's Kirrha plain, which was part of the god's territory, was emphasised on several occasions by Greek authors and orators of the fourth century BC. The hieromnemons were obliged to control the observance of the prohibition of cultivation and other rules by regular inspections. However, the land was not left waste: apart from some of the horse-races in honour of Apollo that probably took place on this territory, it was used mainly as grazing land for Apollo's sacred flocks. ${ }^{40}$ Denis Rousset discusses the possibility that privately owned animals were allowed to pasture on the god's land. ${ }^{41}$

Apart from mountain grazing, wild animals and wild vegetation with olives and other trees or with thin timber and brushwood that could be used as construction material or for other purposes, could belong to such uncultivated sacred land. Moreover, wild vegetation and beekeeping could be part of the diet, and hunting was not only an élite pastime. All these and more potential forms of usage of uncultivated land make it obvious that such sacred land did not had to be unproductive. ${ }^{42}$

A case of debate over the last decades is the "transhumance versus agro-pastoralism" debate. ${ }^{43}$ However, it seems convincing

traditions, cf. D. Rousset, Le territoire de Delphes, pp. 183-192 and M. Horster, Landbesitz, pp. 120-125.

40. Apollo's live-stock was composed of sheep, goats, horses and cattle: with further references? Cf. D. Rousset, Le territoire de Delphes, pp. 192-205.

41. Ibid., pp. 192, 204. There is no direct evidence (e.g. epinomia) for private pasturage or the explicit allowance of transhumance of private herds through sacred land neither for this specific case of Delphi nor for other territories owned by a deity. Hamish Forbes, "The uses of the uncultivated landscape in modern Greece: a pointer to the value of the wilderness in antiquity?", in: Graham Shipley, John Salmon (eds.), Human Landscapes in Classical Antiquity. Environment and Culture, London/New York 1996, pp. 68-97, esp. pp. 74-76, discusses the question of ownership of uncultivated land and refers explicitly to the honorific decrees rewarding non-citizens with the right of grazing (epinomia) and less often with wood-cutting (epixylia) as indicator to public uncultivated land.

42. E.g. Forbes, "Uses of Landscapes" with references to literature. On hunting, Robin Lane Fox, "Ancient hunting from Homer to Polybios", in: G. Shipley, J. Salmon (eds.), Human Landscapes in Classical Antiquity. Environment and Culture, pp. 119-153 with a focus on the literary topoi of hunting as pest control, as leisure and competition, and the meat as addition to the banquets of the wealthy. John K. Davies, "Classical Greece: Production", in: Walter Scheidel, Ian Morris, Richard Saller (eds.), The Cambridge Economic History of the Greco-Roman World, Cambridge 2007, pp. 333-361, esp. pp. 339-341 on uncultivated land as grazing land and source of nutrients like nuts and honey.

43. Hamish Forbes, "The Identification of Pastoralist Sites within the Context of Estate-Based Agriculture in Ancient Greece: Beyond the 'Transhumance versus 
that large areas of uncultivated, barren or rocky land were made productive by pastoralism, and, that in addition, animal husbandry could be well integrated with the arable and agricultural activities of large estates. ${ }^{44}$ If pastoralism was an important economic and ecologic factor in the farming of lands, one has to assume that this was likely the case for the cultivated (leased out or not) sacred lands. But as it seems, at least in the cases where we have explicit regulations the grazing of livestock was not in the interest of most of the deities' property-administrators, who were responsible for such leges sacrae. In addition, no epinomia rule is known in the context of a sanctuary. ${ }^{45}$ On the other hand, the uncultivated land of border-sanctuaries, especially those on hillsides and mountainsides, were probably attractive as grazing resource, not only for the sacred cattle, pigs, sheep, goats, etc. that were needed for animal sacrifices. ${ }^{46}$

\section{RULES THAT GUARANTEE THE SACREDNESS OF LAND}

Several regulations in sacred laws prohibit the use of the products, the woods as well as the waste of the sacred land. ${ }^{47}$ In

Agro-pastoralism' Debate", ABSA 90 (1995), pp. 325-338, gives an excellent overview over the current debates.

44. Cf. H. Forbes, "The Identification", pp. 329, 331.

45. The early $6^{\text {th }}$ century inscription of the Athena Alea cult at Tegea seems to establish specific rule for the pilgrims and their animals, including grazing-rights during the period of the main festival. On this and few other inscriptions down to the late fourth century BC, M. Horster, Landbesitz, pp. 128-136. On Cretan regulations of grazing rights and on the surveyor-duty of the "Eunomia" council concerning the sacred streets (and the theft of livestock?) in Cretan cities, Angelos Chaniotis, Die Verträge zwischen kretischen Poleis in der hellenistischen Zeit, Stuttgart 1996, pp. 114-120. Few more inscriptions are connected to grazing on sacred property, see Christophe Chandezon, L'élevage en Grèce (fin $v^{e}-f i n I^{e r}$ s. a.C.). L'apport des sources épigraphiques, Paris 2003, pp. 293-307 and with a detailed discussion p. 89 on the Gonnoi versus Herakleion arbitration at the Macedonian border, after 218 BC?; p. 179 on the prohibition of grazing in temene (sacred lands) in Crete; p. 248-250 on the protection of the Zeus sanctuary at Labraunda 203 BC; p. 250-251on that of Zeus Panamareus in Caria at an unknown date.

46. See H. Forbes, "The Identification", p. 329f.

47. Apart from the classical-time rules and provisions to safeguard the non-economic aspect of sacred lands, presented by M. Horster, Landbesitz, such rules are attested as well in later times, e.g. the protection of sacred woods, Syll. ${ }^{3}$ 1157 II lines 73-84 (= F. Sokolowski, LSCG (1969) 84, 11. 4-14) concerning Apollo Koropaios' property in Korope, ca. 100 BC; F. Sokolowski, LSCG Suppl. (1962) 81, lines 2-9 concerning the sacred woods of Hera at Samos, first century AD. 
all these cases, the sacredness is connected to the prohibition of human intervention. In addition to the deliberately not using sacred land for cultivation and for leasing out, there were as already mentioned several kinds of more or less natural sanctuaries, which had no direct economic usage and probably did not add to the cults' income if a priest or priestess was appointed for such a cult in a natural sanctuary at all, if certain more or less costly sacrifices were performed in these natural places on a regular basis. I have already mentioned as well, that the modern viewer, perhaps even the ancient visitor was not always able to recognise such a place as sacred at first sight. Therefore, I would venture to suggest that sacred land was not automatically part of a religious landscape. Cultivated land, land leased out for agricultural usage had no other visual and probably religious impact on the peasant who cultivated the land, on the passer-by who travelled over land or had some business in the chora of a city-at least the cases in which the cultivated sacred land was part of a cultivated environment.

Such leased out cultivated land may have impressed the reader of the long inscriptions presented in the middle of the city or in the sanctuary next to the temple. As the long and nearly unreadable text of the Athenian inventories, such inscriptions demonstrated the strength of the deity and the prosperity of the cult. Thus, in the reader's, or viewer's mind-if he was not able to read the long texts with tiny letters-the documentation of the leases of sacred land might have generated a virtual and mental religious landscape including the vision of large estates of landed property of the respective deity.

Less virtual is the share of sacred land in the creation of religious landscapes that was different from its surrounding area and was thus clearly marked out as sacred. This might have been the land that immediately surrounds the walled sanctuary with shrine and altar. In such a case it might not have mattered if the land was cultivated or not, as long as it was clearly connected with the sanctuary. Land surrounding a sanctuary could eventually or temporarily receive a specific religious quality or one might argue a less religious but social and economic quality-for example in all cases when a festival with fairs and markets took place in the proximity of the sanctuary.

Apart from the immediate closeness to a shrine, the quality and the appearance of the land might both have a major impact. The natural sanctuaries with groves for example became only 
visually and virtually specific if there was something that made them different from their environment. In many cases it may have been the change from human culture to divine nature, from the normal, for example a normal tree, to the exceptional, a tree divided by lightning, that made the place so specific, so sacred. Concepts of sacredness as combined with nature, with humanly untouched, with uncultivated nature, might have been a strong implement to transform a domesticated human landscape into a divine one.

\section{NATURe AS PART OF THE DIVINE ORDER, DIVINE LANDSCAPES AS HYPER-NATURE}

Neighbouring Pan and the Nymphs is a literary feature of antique descriptions of country life. ${ }^{48}$ Accordingly, Robert Parker claims that the Attic Pan had been introduced to Athens not so much as a rural deity, a "herdsman's god" rather than a post-Marathonian "pastoral dream" of ancient authors. ${ }^{49}$ Again, some Greek texts establish imagined settings within a sacred landscape. Notably the heroic landscape of Philostratus' second/third-century AD "On Heroes" is a cult-site full of beauty, sweetness, floral fragrance, vegetal abundance and fertility: a divine place in every respect. ${ }^{50}$ The pseudo-homeric hymn of Apollo with its descriptions of a beautiful, quiet and peaceful sacred grove is probably the earliest such example, ${ }^{51}$ although in terms of phraseology and style the early texts have less emphasis on the hyper-pastoral and above-man-made cultural countryside than the imperial time authors Philostratus and Pausanias. Pausanias introduces his favourite sites and monuments with a "théas áxion" as a kind of exclamation mark indicating the

48. E.g. Alci. 2.8 (late $2^{\text {nd }}$ or $3^{\text {rd }}$ cent. AD) discussed by Nicholas F. Jones, Rural Athens under the Democracy, Philadelphia 2004, pp. 181-186. This pastoral mythology and its connection to the countryside is presented by Philippe Borgeaud, The Cult of Pan in Ancient Greece, Chicago/London 1988 (French publ. in 1979), pp. 47-73 with notes p. 206-220.

49. Robert Parker, Athenian Religion. A History, Oxford 1996, p. 167. Parker's arguments are contested by N. F. Jones, Rural Athens, p. 185.

50. Phil. Heroic. 3.3-4, 4.10, 5.2-3. The above follow Tim Whitmarsh, "Performing heroics: language, landscape and identity in Philostratus' 'Heroicus"", in: Ewan Bowie, Jaś Elsner (eds.), Philostratus, Cambridge 2009, pp. 205-229 esp. pp. 212-13.

51. M. Horster, Landbesitz, pp. 96-98. 
heavenly beauty or the outstanding grandeur of the recommended site. $^{52}$ In the case of the Corycian cave in Phocis (10.32.2) he emphasizes the extraordinary and exceptional stalagmites, the unusual ceiling height of the main cave and the magic of its natural light in the cave.

Nature itself may be described as of divine beauty but more often ancient authors seem to connect extraordinary beauty with sacred places, with places of cult, thus transforming sacred land into a religious landscape, creating a sacred space which is defined by its human-made cult-context and by its natural divinity, a hyperhuman, divine beauty. ${ }^{53}$

\section{FinAL REMARKS}

The above mentioned concepts and "realities" of sacred land over the centuries have been harmonised in their presentation by the chosen definition of the paper's subject. Therefore at least some problems, discussions and potential differences might be addressed in these final remarks. As concerns the Roman period, it may be

52. Christian Jacob, "Paysages hantés et jardins merveilleux. La Grèce imaginaire de Pausanias", L'Ethnographie, 122 vol. 76 (1980), pp. 35-67, esp. pp. 41, 54-64; Anne Jacquemin, "Les curiosités naturelles chez Pausanias", in: Gérard Siebert (ed.), Nature et Paysage dans la pensée et l'environnement des civilisations antiques, Paris 1996, pp.121-128. Whereas Jacob discusses the virtual, the imaginative landscapes and refers to the divine nature of some of the mirabilia of nature, Anne Jacquemin focuses on the realia: the theas axionplaces of interest are the Apollo-sanctuary of Dodona, the Zeus-temple at Nemea, the theatre of Delphi, the grotto of Pan at Marathon, the source of Orchomenos (Arcadia)-connected to the Artemis-sanctuary(?)-and the cave of the MotherGoddess in Phocis (A. Jacquemin, p. 122f.).

53. For a discussion of theories concerning the sacredness of nature in modern ecology and bio-theory, see Kraft E. von Maltzahn, Nature as Landscape. Dwelling and Understanding, Montreal/London/Buffalo 1995, pp. 19-26. A selection of Pausanias' recommendation of natural sites, of sacred groves and grottos, of plants and single trees highlighted and connected to mythology is discussed by A. Jacquemin, "Les curiosités", pp. 124-127. Even in those cases were Jacquemin does not mention explicitly the connection of natural sites to gods and deities, most often the Pausanias' reader is provided with such a context. On Plato, Kritias 111 and the connection of plentiful streams of springs and rivers, of tall trees and boundless pasturage connected with former choices of places of worship and the rather literary not geographical interpretation of this passage, Oliver Rackham, "Ecology and pseudo-ecology", in: G. Shipley, J. Salmon (eds.), Human Landscapes in Classical Antiquity. Environment and Culture, pp. 16-43, esp. p. 33-35. 
questioned if there is a visible and obvious gap in the treatment of sacred land and in the concept of sacred landscapes. At least, some boundary disputes, the engagement of the imperial administration in these disputes, the promotion of some sanctuaries and cults with privileges, money and prestigious buildings, the imperial cult as a new focus in the local elites' careers, all these phenomena make it obvious that the financial, political and religious context of the sanctuaries' (landed) property had changed in the Roman imperial period. However, it is difficult to discuss the results of these changes in detail. E.g. Robin Osborne claims that the end of the autonomy of the Greek city furthered the urban limitation of cities and made the countryside a more or less independent part of the Roman province. ${ }^{54}$ Yet, the theory of the end of the Greek city is a matter of debate: although the cities lost their autonomy and thus their former political strength, the Greek cities had not only various political and judicial statuses in relation to each other and to the supra-structure, they also continued making local politics. Their local elites were economically strong and politically self-conscious-not only because of their cultural heritage. The Greek most often democratically organised cities with astu and chora, with demos and boule, with archontes and hiereis etc. did not come to an end under the modified political conditions of the Hellenistic period and Roman domination.

However, since the late first century BC, new ports, new cities and transformations of the infrastructure as well as the road and path network especially in the West of mainland Greece, lead to shifts of trade roads, of centres of wealth-accumulation and economic exchange. ${ }^{55}$ Some Roman interventions as to the ownership of soil and of sanctuaries are attested in the first centuries BC and AD, but only few concern sanctuaries and cults in the province of Achaia. ${ }^{56}$

54. Robin Osborne, Classical Landscape with Figures: the Ancient Greek City and its Countryside, London 1987, esp. pp. 192-195 summarises the development from the embeddedness of the classical city in the countryside to the separation of city and country during the Imperial period to finally the later Roman era when "the countryside ran itself almost independently of the town" (193). Osborne's position is criticised by Denis Rousset, "The City and its Territory in the Province of Achaea and 'Roman Greece"', HSCPh 104 (2008), pp. 303-337.

55. Athanasios Rizakis, "Les colonies romaines des côtes occidentales grecques. Populations et territoires", Dialogues d'histoire ancienne 22/1 (1996), pp. 255-324.

56. Examples like the ones concerning the territories of Messene (loss of territory in favour of Laconia), of Corinth (ager publicus and distribution land), or 
Pausanias' descriptions recall for the mid-second century AD at least as many degenerated rural sanctuaries as wealthy and well visited sanctuaries in urban centre and the chora-not only in the new commercial centres of Roman Achaia, but in other, economically less privileged areas of Greece as well. The financing of some of these sanctuaries with the leasing out of sacred land is attested well into the Roman period.

Notwithstanding the many changes in the "religious landscapes", especially with the rituals and monuments connected with the increase of cult associations as well as with the integration of the imperial cult and its shrines, statues and altars into the civic cult, the concept of the sacred land, the land of the gods remained obviously unchanged-not always in quantity or economic efficiency, but probably in the specific quality, the sacredness, attached to this land. However, as concerns the differences between mainland Greece and Asia Minor and the various changes in the treatment of sacred property in the Hellenistic and Roman Imperial Period, there is still work to be done.

"Sacred land" and "land belonging to a deity" are no modern terms but the translations of ancient terms and realities which could take various forms in their manifestations. Not all sacred land, but at least some of its manifestations were part of what we may call "religious landscape", an antique as well as a modern narrative, intellectual and/or analytical construct of a variety of social, cultural and religious characteristics and expressions-a construct shaped by its respective modern beholders.*

Historisches Seminar, Alte Geschichte

Universität Mainz

D - 55099 Mainz

the relocation of the Ares-temple to Athens, the removal of statues of the sanctuaries of Athena Alea at Tegea and Artemis Laphria at Kalydon are cited by Alcock, Graecia Capta, 175-180; D. Rousset, "The City", pp. 316, 320; A. Rizakis, "Les colonies romaines des côtes occidentales grecques", pp. 269-273.

* This article is revised from the paper I presented to the colloquium "Qu'est-ce qu'un paysage religieux?" in Paris in April 2009. My thanks go to Professor François de Polignac and Professor John Scheid, for organizing the meeting and inviting me to speak at it. The article is part of the DFG funded project "Religiöse Funktionsträger" in the context of the SPP 1209: Die hellenistische Polis als Lebensform. 